УДК 37(09)(477)

DOI: 10.24919/2519-058x.10.159532

\title{
Nadiya FEDCHYSHYN
}

PhD hab. (Pedagogic), Associate Professor, Head of the Department of Foreign Languages of I. Ya. Horbachevsky Ternopil State Medical University, 1 Maidan Voli Street, Ternopil, Ukraine, postal code 46001 (fedushunno@tdmu.edu.ua)

ORCID: http://orcid.org/0000-0002-0909-4424

ResearcherID: Q-5422-2016 (http://www.researcherid.com/rid/Q-5422-2016)

Scopus ID: 57202833382

(https://www.scopus.com/authid/detail.uri?authorld= 57202833382)

\section{Timur MAGSUMOV}

PhD (History), Associate Professor, Deputy head of the laboratory, Laboratory of Professional and Pedagogical Training, International Network Center for Fundamental and Applied Research, 1150 Connecticut Ave NW, STE 900, Washington, USA, postal code 20036; Life member, History of Education Society, Glasgow, UK; Associate Professor, History and its Teaching Methods Department, Naberezhnye Chelny State Pedagogical University, Naberezhnye Chelny, Russia (Washington, USA) (nabonid1@yandex.ru)

ORCID: https://orcid.org/0000-0003-0117-7513

ResearcherID: I-5300-2013 (https://www.researcherid.com/rid/I-5300-2013) Scopus ID: https://www.scopus.com/authid/detail.uri?authorId=55799874500

\section{Надія ФЕДЧИШИН}

доктор педагогічних наук, дочент, завідувач кафедри іноземних мов Тернопільського держсавного медичного університету ім. І.Я. Горбачевського, вул. Майдан Волі, 1, м. Тернопіль, 46001, Україна (fedushuпnо@tdmи.еdu.иа)

\section{Тимур МАГСУМОВ}

кандидат історичних наук, доцент, заступник голови лабораторії професійної i педагогічної підготовки, Міжнародний мережевий центр фундаментальних i прикладних досліджень, Коннектикут-Авеню Норт-Вест, 1150, кімната 900, м. Вашингтон, США, 20036; пожиттєвий илен, Історико-освітнього товариства, м. Глазго, Великобританія; доцент кафедри історії та методики ї̈ викладання, Набережночелнинський державний педагогічний університет, м. Набережні Челни, Російська Федераиіл (nabonid1@yandex.ru)

Бібліографічний опис статті: Fedchyshyn, N. \& Magsumov, Т. (2019). The educational activity in Halychyna at the beginning of the $20^{\text {th }}$ century: historical-pedagogical analysis. Skhidnoievropeiskyi Istorychnyi Visnyk [East European Historical Bulletin], 10, 66-73. doi: 10.24919/2519-058x.10.159532

\section{THE EDUCATIONAL ACTIVITY IN HALYCHYNA AT THE BEGINNING OF THE $20^{\text {TH }}$ CENTURY: HISTORICAL-PEDAGOGICAL ANALYSIS}

Summary. The purpose of the research is to highlight the important historical aspects of the educational policy in Halychyna at the beginning of the $20^{\text {th }}$ century on the basis of an interdisciplinary 
approach. The reseach methodology. A complex of general and special scientific methods is used: the comparative analysis, the systematization of scientific, educational and methodical literature, documents, periodicals; historical-genetic, historical-comparative; expert method (analysis of problems with evaluation of results). The scientific novelty. The historical peculiarities of the educational activity in the beginning of the $20^{\text {th }}$ century have been highlighted in the article. The main attention has been drawn to economic factors, particularly, to providing funding allocation per student, to the level of illiteracy in different countries, to the impact of these factors on the level of national income. The attention also has been paid to the educational policy of foreign countries with regard to the Ukrainians. For history, it is not only important to study macroeconomic indicators at the level of evaluation of the consistency of pedagogical systems development, pedeutology, management of educational institutions, educational policy of the state, but also the peculiar microanalysis at the level of the development of an individual personality. The achievements of prominent thinkers of the past have been reconsidered on the basis of the principle of innovation. Andrei Sheptytsky's pedagogical system has been used for illustrative purposes. J.-P. Herbart followers' direct and indirect impact on the justification of the educational process fundamentals have been singled out in the context of interactions of different nations' cultures. Conclusions. The use of indepth panoramic investigations together with the history of individual families, a personal approach will contribute immensely to the past events reconstruction, the possibility of even more effective use of the past experience for state-building processes of the present and future.

Key words: Halychyna, educational activity, regularity, history, pedagogy, economics.

\title{
ОСВІТНЯ ДІЯЛЬНІСТЬ В ГАЛИЧИНІ ПОЧАТКУ ХХ СТ.: ІСТОРИКО-ПЕДАГОГІЧНИЙ АНАЛІЗ
}

\begin{abstract}
Анотація. Метою пропонованої розвідки є виокремлення важливих історичних аспектів освітньої політики в Галичині на початку XX ст.. на засадах міждисциплінарного підходу. Методологія дослідження: використано комплекс загальнонаукових і спеціальних методів: порівняльний аналіз, систематизачія наукової, навчально-методичної літератури, документів, періодичних видань; історико-генетичний; історико-порівняльний; експертний метод (аналіз проблем з оцінкою результатів). Наукова новизна: висвітлено історичні особливості освітньої діяльності початку XX cm. Закиентовано увагу на економічних чинниках, зокрема, на фінансуванні з розрахунку на одного учня, рівні неписьменності в різних крайнах, впливі ичих чинників на рівень національного доходу. Звертається увага на освітню політику іноземних краӥн у ставленні до українців. Для історії важливими є не лише дослідження макропоказників на рівні оцінки закономірностей розвитку педагогічних систем, педеутології, управління закладами освіти, освітньої політики держави, але й своєрідний мікрорівень на рівні розвитку окремої особистості. На засадах принщипу новаторства переосмислено досягнення видатних мислителів минулих років. Як приклад використана педагогічна система Андрея Шептицького. В умовах взаємодї культур різних народів виокремлено безпосередній та опосередкований вплив послідовників Й.-Ф. Гербарта на обтрунтування основ освітнього прочесу. Висновки. Використання глибинних панорамних досліджень в єдності з історією окремих родин, особистісний підхід сприятиме реконструкиї минулих подій, можливості ще більш ефективного використання досвіду минулого для державотворчих процесів сьогодення і майбутнього.

Ключові слова: Галичина, освітня діяльність, закономірність, історія, педагогіка, економіка.
\end{abstract}

Problem statement and analysis of researches and publications. The beginning of the twentieth century is characterized by the quantitative and qualitative changes in the socio-economic development of most countries. At first glance, this process is characterized with a jump-like character. In fact, during the second half of the nineteenth century, a peculiar preparatory period took place. Those countries that timely decided on their priorities chose the right direction of education policy, funded the system of a general education and a professional education, and received significant dividends in the future. The specific tendencies in the development of those countries and regions are of particular interest, which 
are characterized by multiculturalism, the mutual influence of different cultures, the struggle to establish national interests, taking into account the historical traditions of their people and the achievements of other countries. That is why Halychyna has evoked and will evoke interest of historians, economists, educators, who will analyze the main problems, gradually approaching to understanding the regularities of the process.

The historical regularities of an educational activity in Halychyna have a number of specific features. The first one is the dynamics of changes in the political, socio-economic life. Secondly, a significant number of studies conducted require the search for new aspects, generalizations, taking into account the possibilities of a systemic, interdisciplinary approach. Thirdly, the review of the literature allows us to make a controversial conclusion regarding the increased attention of Polish researchers, at least in quantitative terms, to various issues of public life in Halychyna.

As an example, we would like to consider two literary sources. Let us pay attention to the multivolume edition of «Galicja i jej dziedzictwo» (Meissner, 1995; Meissner, 1996). The first volume (History and Politics) was published in 1994, and in 2016, the $24^{\text {th }}$ volume was already published. In the context of our study, the content of the third and sixth volumes is of a particular interest. The two volumes of Franciszek Bujak's Halychyna, which were published in 1908 (Bujak, 2014a) and 1910 (Bujak, 2014b), deserve a special attention. The fact that the reprint was issued in 2014 shows the relevance of this work by «the father of Polish history of farming». Another scientific paper worth mentioning is «Twórcy nauk o wychowaniu w środowisku akademickim Lwowa (1860 - 1939)» by K. Szmyd (Szmyd, 2003).

An important place in the historiography of the problem is taken by the monographs and the doctoral dissertations. In recent years, the attention to the events in Halychyna has been steadily increasing. This is evidenced by the emergence of a series of the original studies devoted to an analytical assessment of socioeconomic processes, the role of Halychyna $\mathrm{n}$ students, the significance of the intelligentsia of the region, its clergy, journalists in raising the level of culture and a national identity (Degtyarev, Zavhorodnia, Polyakova, 2018).

At the same time, there is a significant number of issues left unresolved. First of all, we mean the regularities of the education of the national elite, the combination of general laws with the history of individual families, the assessment of the mutual influence of different cultures, structural, functional, theoretical modelling of an educational activity, a predictive assessment built on the basis of a historical experience.

Therefore, the purpose of the given research is to highlight the important historical aspects of the educational policy in Halychyna at the beginning of the $20^{\text {th }}$ century on the basis of an interdisciplinary approach.

Presentation of the main content. To understand the specifics of the educational activity in Halychyna, it is important to take into account the general historical tendencies characteristic of the beginning of the 20th century. In the monograph, which became the basis of the doctoral dissertation by A. Vykhrushch (1993), the author emphasized the role of the economic expediency of investments into education. According to the well-known economist A. Marshall, the economic value of one genius in industry is greater than the expenses necessary to educate thousands of people. Moreover, in order to improve the material well-being of the people, in the first place the development of schools must be facilitated. Most countries have solved the problem of a compulsory primary education in the $19^{\text {th }}$ century. The results are obvious. In $1900-1905$, the illiteracy rate per 1000 people was the following: Switzerland - 0, German - 20, Sweden - 21, Great Britain - 80, the USA - 107, France - 150, 
Austria - 356, Hungary -478 , Russia (1897) - 747. The national income by M. Mulhall was the following: the USA - 309, Great Britain - 299,3, France - 268,5, Belgium - 239,1, Sweden - 199,2, Germany - 190,9, Norway - 183, Switzerland - 160, Austro-Hungary 135,7, Italy $-109,3$, Russia $-66,4$.

The interest to this problem in different countries is proved by their expenses for education per student. The average expenses per student were the following (according to Russian literary sources, expressed in Russian ruble): the USA - 50,8, Switzerland - 28,4, Great Britain - 22,7, Norway - 18,4, Sweden - 17,7, Japan - 6,2, France - 2,7, Russia - 1,2 (Vykhrushch, 1993, p. 34-35). These factors have had a significant impact on the training of the professional elite in every country.

Following the principle of innovation it is necessary to reconsider the outstanding thinkers' achievements of the past. For illustrative purposes, the pedagogical system of Andrei Sheptytskyi can be mentioned. The analysis of Metropolitan Andrei's didactic views allowed the researchers to distinguish the following ideas that do not lose their urgency: «the collaborative activity of priests and intellectuals in order to raise the level of people's culture; the motivation that is based on the principles of service to God and people; the intellectual upbringing as a means of human development; the intellectual upbringing in the context of overcoming economic hardships; the intelligentsia's responsibility for educational activities; the health preserving health, the fatigue preventing; the development of the memory by means of summarizing and repetition of the main thoughts; the spiritual exercises (recollections); the shared reading; the novelty and relevance; the clarity, the apprehensibility, the simplicity, the figurativeness and comparison; listening to good sermons; the humour; learning for life; the development of students' independence, the identity, the initiative; the development of intellect and willpower; the cause and effect connections between phenomena; the development of the gift of preaching; the avoidance of excessive criticism; the unity and coordination of the tutors' work; the understanding of the learned material; the meaningfulness of the questions; the combination of theoretical generalizations with the specific facts; silence; the rational use of time; concentration; the creation of scientific centres; the School of Prayer» (Vykhrushch, 2018b).

The naturally-determined interest arises of how the above-mentioned ideas were developed, which of them preserved their urgent character in subsequent years and what new aspects that were inherent in the author's didactic system were substantiated later.

The transnational integrity of the past in the field of history, culture, education is of great interest. We cannot overlook the historical and pedagogical processes in the Austro-Hungarian Empire as they were directly reflected in the educational theory and practice of Western Ukrainian lands. In particular, the influence of Herbartianism in the countries of the Habsburg monarchy has been observed since 1848, that is, since the reform of the system of a public education, which was carried out in order to improve the organization and the content of teaching in accordance with the requirements of pedagogy. Since the second half of the nineteenth century, universities and gymnasia of Austria, and later, Austro-Hungary, are modernized in accordance with the German system. The key ideas in the Austro-Hungarian education system are distributed among the supporters of the Herbartian doctrine (Brezinka, 2003, p. 190; Engelbrecht, 1984, p. 35). Thus, we observe the active nature of the educational processes in Halychyna and Bukovyna, which were part of the Austrian (1804-1867), and subsequently the Austro-Hungarian Empire (1867 - 1918), under the Herbartian model of cultural-historical, socio-economic and educational development in these lands for different historical periods. 
In his monograph «Classical education in the Western Ukrainian lands $\left(19^{\text {th }}-\right.$ first half of the $20^{\text {th }}$ century). The Historical and Pedagogical Aspect», I. Kurliak highlights the content of education in the educational institutions of Halychyna and Bukovyna and offers a comparative analysis of the content of educational policy and system in Russia and Austria-Hungary. The author notes that the Austro-Hungarian educational policy, which focuses on the Germanization of schooling in Halychyna and the implementation of a number of reforms, in addition to the deficiencies, has contributed to the rise of a cultural life and provided a certain educational level (Kurliak, 2000, p. 6). In the paper "The Education of Austria in the $19^{\text {th }}$ and early $20^{\text {th }}$ Centuries", M. Miaskovskyi discloses the content and the main directions of the state's regulation of teachers' training and the professional development in the Habsburg Monarchy and in Western Ukraine, in particular, emphasizing the fact that teachers had the status of the state employees (Miaskovskyi, 2008, p. 112).

The foreign influence was manifested in determining the content of education, in particular, in the development of curricula for various types of educational institutions (gymnasia, public schools, lyceums), which clearly proves the study of two fields of disciplines suggested by J.-F. Herbart: historical and philological (religion, reading, writing, languages (German and a second foreign one: Hungarian, Polish, partly Ukrainian) and mathematical sciences (Arithmetic, Geometry, Geography, Nature, Chemistry, Physics) (Fedchyshyn, 2015, p. 64).

The Teaching Seminaries functioned according to the model of the educational institutions of the Herbartians K.-V. Stoy, T. Ziller, G. W. Rein. The Herbartian theory of step-bystep development, the concentration of training, formal degrees were introduced into the educational process of teaching institutes, and the teaching material was recommended to be presented in accordance with the pedagogical concept of J.-F. Herbart, set forth in "General Pedagogy" (Fedchyshyn, 2015, p. 90).

A similar picture can be observed in the preparation of the scientific elite. In the higher educational institutions, a new generation of scholars was trained. We note the fact that several habilitative papers have been presented in the German-speaking Charles University of Prague - Wendelin Toischer (1896), P. Durdik (1887) and F. Drtina (1898), two in Krakow L. Kulchinskie (1880), Antoni Karbowiak (1905) and two others at the University of Lviv A. Danish (1895), B. Mankovsky (1903). It should be emphasized that three out of four doctoral studies were prepared by students of J.-F. Herbart at the University of Vienna (Téodor Vogt) (1865), Alois Höfler (1895), Wilhelm Jerusalem (1903)). The doctrine of the J.-F. Herbart and number of his students and supporters (M. W. Drobisch, L. von Strümpell, T. Weitz, G. Hartenstein, F. W. Dorpfeld, K. Kerbach, K. W. Mager, G. A. Lindner, K.-V. Stoy, T. Vogt, T. Ziller, G. W. Rein, O. Vilman) became especially popular in Germany, Austro-Hungary, and later in all European countries as an interesting scientific model of educational theory and practical training for solving a number of topical issues of education, didactics, pedeutology.

It is fundamentally important that in the context of the planned reforms in Ukraine, the idea of acceptability of humanistic traditions of world and national education was preserved. That is why there is an urgent need to find a foreign pedagogical experience, in particular the German-speaking countries (Germany, Austria, Switzerland), who embodied the advanced ideas of European pedagogical science and had a significant impact on the formation of pedagogical science and practice.

For history, it is not only important to study macroeconomic indicators at the level of evaluation of pedagogical systems' development consistency, pedeutology, management of educational institutions, educational policy of the state, but also the peculiar microanalysis at the level 
of the development of an individual family, personality. The written works of the students of the past years are of special interest. Actually speaking, thanks to such written documents, we can approach to a certain extent to understanding of the regularities of the educational process organization. Along with the memorial literature and scientific researches of the studied period we obtain a certain kind of the tool of a historical and pedagogical research.

For example, A. Vykhrushch has conducted an analysis of the content of the student's notebook with Ukrainian exercises for 1936 - 1937 academic years. The owner of the notebook was a pupil of the eighth grade of the gymnasium: The first page of the notebook remained blank. The text began on the second page, so that the third and all subsequent odd ones were intended for the «correction». If a student made a mistake then on those particular pages they wrote a sentence with the corrected error. It was a specific kind of the reference scheme that was aimed at improving the standard of writing culture. The schoolgirl made the following mistakes in a school exercise. On the second page of her notebook there were two of them: «Vchera zachavsia shkilnyi rik» (in English - «Yesterday the school year began»)» and «Nyni ya khochu, bodai v chasty, perelyty na papir svoii dumky i vrazhinnnia_vyklykani pershym dnem» (in English - «Today I want, at least partially, to write down on the paper my thoughts and impressions induced by my first day»). On the third page, after the mistakes had been underlined with the red coloured ink by a teacher, only two sentences were written: «Vchora zachavsia shkilnyi rik» and «... svoii dumky i vrazhennia see, the letters that were written incorrectly and the skipped comma in the sentence stipulated the schoolgirl to rewrite the corrected fragments along with the main text on the separate page. Such attention to erroneous actions deserves approval and is worth to be implemented in present-day conditions. This is important both at the level of the methodology and in the development of modern didactic systems. Each school exercise provided the choice of one of the three topics. The following list was suggested in the analyzed school notebook: «My thoughts and feelings at the beginning of the VIII class», "Who of the Ukrainian writers and women writers makes the deepest impression on me and why?», «Horoba (ramova tema)» (in English ramova tema - the main topic); «What kind of impressions did the collection of I. Franko's poetry «Zivyale lystia» (in English - «Faded leaves») made on me?», «Theatre (ramova tema)», «What social work do I consider to be the best and why?», «What title do I want to choose and why?», «What the people's leader should be like?» (Based on I. Franko's poem «Moses»), «What kind of impressions did the film «In a moment of happiness?» make on me?»; «The Strength of the Word», «A Woman in Ukrainian Literature», "Zymova Zaviriuha» (in English - «Winter Snowstorm»). The list of themes allows us to draw a conclusion about the peculiar vector orientation on the development of the autonomy of thinking, creativity, upbringing of a civic position and the combination with the practice of daily life (Vykhrushch, 2018a).

The emphasis has been made on the optimistic completion of the written assignment: «... let failures strengthen my character. In order to make a good thing of iron, we throw it into the fire, so that a man could call himself mature, he must go through a solid school of life. I do not want to get away from it. I want my certificate of maturity to be true, proved by actually obtained knowledge, objectively well-developed mind and the noble soul. If I am not able to comprehend it throughout the running year, then I will not give up, but I will continue to work. Such thoughts ran on me in my first day at the eighth grade. Life will show me which of them are good and which are not. Today it felt extremely well. The initial fear passed, and it was replaced by some kind of joy: this year I will be able to become a mature man». 
An important place in a modern historical research is taken by the search for regularities of the process of a regional development, as well as the systems of a higher order. At the beginning of the $20^{\text {th }}$ century, a complex process of correlating the level of population literacy, expenses per student, a national income began. Those countries that realized these ratios earlier obtained better starting conditions for the next decades. The absence of own independent statehood delayed the development of national culture. The phenomenality of Halychyna was manifested in the fact that even under such unfavourable conditions the educators of the level of Andrei Sheptytsky, the clergy, teachers, journalists, and writers formed the basis for future liberation struggles.

Conclusions. We consider that the level of modern science makes it possible to actualize the possibility of a gradual transition from the accumulation of a large mass of little-known materials to the search for the historical development regularities. The interdisciplinary, systematic approach, the combination of the advantages of structural, functional, theoretical modelling, as well as the comprehensive assessment of mutual influences, especially in a multicultural environment are acquiring special actuality. The use of in-depth panoramic investigations together with the history of individual families, a personal approach will contribute immensely to the past events reconstruction, the possibility of even more effective use of the past experience for state-building processes of the present and future.

Acknowledgments. We express our sincere gratitude to Doctor of Pedagogy, Professor Anatolii Volodymyrovych Vykhrushch for his kind and helpful recommendations during our research.

Funding. The authors received no financial support for the research, authorship, and/or publication of this article.

\section{BIBLIOGRAPHY}

Brezinka, W. (2003). Pädagogik in Österreich. Die Geschichte des Faches an den Universitäten vom 18. bis zum Ende des 20. Jahrhunderts (Bd. 2) [Pedagogy in Austria. The history of the subject at the universities from the 18th to the end of the 20th century (Vol. 2)]. Wien: Verlag der österreichischen Akademie der Wissenschaften, 1023 p. [in German].

Bujak, F. (2014). Galicya [Halychyna] (T. 1). Rzeszów, wydawnictwo librapl, 561 s. [in Polish].

Bujak, F. (2014). Galicya [Halychyna] (T. 2). Rzeszów, wydawnictwo librapl, 509 s. [in Polish].

Degtyarev, S. I., Zavhorodnia, V. M. \& Polyakova, L. G. (2018). On the Establishment of the Ruthenian (Ukrainian) University in Austria-Hungary and Its Coverage in «Kievskaya Starina» Journal // European Journal of Contemporary Education, 7 (4), 911-917. [in English].

Engelbrecht, H. (1984). Geschichte des österreichischen Bildungswesens. Erziehung und Unterricht auf dem Boden Österreichs (Bd. 4) [History of the Austrian education system. Education on the soil of Austria (Vol. 4)]. Wien: Österreichischer Bundesverlag, 644 p. [in German].

Fedchyshyn, N. O. (2015). Herbartianska pedahohika v nimetskomovnykh kraiinakh: teoriia i praktyka: monohrafia. [Herbartian pedagogy in German-speaking countries: theory and practice: Monograph] (V. 1). Ternopil: Pidruchnyky i posibnyky, 625 p. [in Ukrainian].

Fedchyshyn, N. O. (2016). Rozvytok idei herbartianskoii pedahohiky $v$ teoriii i praktytsi nimetskomovnykh kraiin (druha polovyna 19 - 20 st.) [Development of the ideas of Herbartian pedagogy in the theory and practice of German-speaking countries (second half of 19 - 20 centuries.)] (Extended abstract of doctoral thesis). Drohobych, 39 p. [in Ukrainian].

Kurliak, I. (2000). Klasychna osvita na zakhidnoukraiinskykh zemliakh (19-persha polovyna 20 st.): Istoryko-pedahohichnyi aspekt. [Classical education in the Western Ukrainian lands $\left(19^{\text {th }}-\right.$ first half of the $20^{\text {th }}$ century): Historical and pedagogical aspect]. Ternopil: Pidruchnyky i posibnyky, 328 p. [in Ukrainian].

Meissner, A. (ed.). (1996). Galicja i jej dziedzictwo. Nauczyciele galicyjscy [Galicia and its heritage. Halychyna's teachers] (Vol. 6). Rzeszów: Wydawnictwo Wyższej Szkoły Pedagogicznej, 168 p. [in Polish]. 
Meissner, A., Wyrozumski, J. (ed.). (1995). Galicja i jej dziedzictwo. Nauka i oświata [Galicia and its heritage. Science and education] (Vol. 3). Rzeszów: Wydawnictwo Wyższej Szkoły Pedagogicznej, 286 p. [in Polish].

Miaskovskyi, M. (2008). Pedahohichna osvita Avstriii 19 - pochatku 20 st. [Teacher Education in Austria in the $19^{\text {th }}$ - early $20^{\text {th }}$ century]. Ternopil: Ekonomichna dumka, 232 p. [in Ukrainian].

Szmyd, K. (2003). Twórcy nauk o wychowaniu w środowisku akademickim Lwowa (1860 - 1939) [Creators of education in the academic environment of Lviv (1860-1939)]. Rzeszów: Wydawnictwo Uniwersytetu Rzeszowskiego, 530 p. [in Polish].

Vykhrushch, A. V. (1993). Trudova pidhotovka uchniv u zahalnoosvitnikh shkolakh Ukraiiny (19-pochatok 21 stolittia) [Labor training of students in secondary schools of Ukraine (19-early 20 centuries)]. Kyiv: Ukraiinskyi derzhavnyi pedahohichnyi universytet im. M. P. Drahomanova, 173 p. [in Ukrainian].

Vykhrushch, A. V. (2018). Innovatsiii mynulykh rokiv yak pryklad dlia suchasnosti [Innovations of the past years as an example for the present]. Materialy mizhnarodnoii naukovo-praktychnoii konferentsiii (Ternopil, 26-27 kvitnia 2018 r.). Ternopil: SMP«Taip», 58-60. [in Ukrainian].

Vykhrushch, A. V. (2018). Rozumove vykhovannia v pedahohichnii systemi Andreia Sheptytskoho (1899-1914 rr.) [Intellectual education in the pedagogical system of Andrei Sheptytsky (1899-1914).]. Pedahohichnyi dyskurs. 25, 72-78. [in Ukrainian].

The article was received on January 18, 2019. Article was recommended for publishing 2.03.2019 